

\section{Sumário}

I. Crônicas do Direito Internacional ...............................................1

REPARAÇÃo DE VÍTIMAS À LUZ DE UM TRATAdo SOBRE EMPRESAS E DIREITOS HUMANOS ............ 3 Ana Cláudia Ruy Cardia

Consumer Social Responsibility as a Requirement for Corporate Social ResponsibiliTY

Nitish Monebhurrun

Crisis in Venezuela: The Brazilian response to the massive flow of Venezuelans in

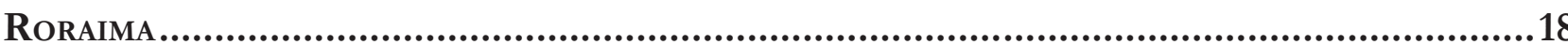

Jacqueline Salmen Raffoul

II. Dossiê EsPecial: Business and Human Rights.........................................23

Some remarks on the third sessions of the Business and Human Rights Treaty Pro-

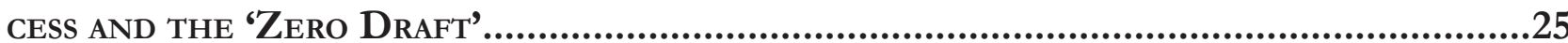

Humberto Cantú Rivera

The United Nations guiding principles on business and human Rights, the State

DUTY TO PROTECT HUMAN RIGHTS AND THE STATE-BUSINESS NEXUS.

Mihaela Maria Barnes

HARdening SOFT LAW: ARE THE EMERging Corporate SOCIAL DisClOSURE LAWS CAPABLE OF GENERATING SUBSTANTIVE COMPLIANCE WITH HUMAN RIGHTS?

Justine Nolan

Del Documento de Elementos al Draft 0: apuntes jurídicos respecto del posible CONTENIDO DEL PROYECTO DE INSTRUMENTO VINCULANTE SOBRE EMPRESAS TRANSNACIONALES

Y OTRAS EMPRESAS CON RESPECTO A LOS DERECHOS HUMANOS

Adoración Guamán 
ACCESS TO REMEDIES AND THE EMERGING ETHICAL DILEMMAS: CHANGING CONTOURS WITHIN THE BUSINESS-HUMAN RIGHTS DEBATE

Justin Jos

LA RESPONSABILIDAD PENAL DE LAS EMPRESAS POR GRAVES VIOLACIONES DE DERECHOS HUMANOS: PRÁCTICA ACTUAL Y DESAFÍOS FUTUROS 130

Daniel Iglesias Márquez

THE ENVIRONMENTAL LAW DIMENSIONS OF AN INTERNATIONAL BINDING TREATY ON BUSINESS AND HUMAN RIGHTS

Juan Gabriel Auz Vaca

Los Objetivos de Desarrollo Sostenible en Europa y su Intersección con el Marco de los Negocios y los Derechos Humanos

Paolo Davide Farah

HumAN RIGHTS AND MARKET ACCESS 203

Danielle Mendes Thame Denny

BusinesS AND HUMAN RIGHTS IN BRAZIL: EXPLORING HUMAN RIGHTS DUE DILIGENCE AND OPERATIONAL-LEVEL GRIEVANCE MECHANiSMS IN THE CASE OF KinRoss PARACATU Gold Mine...222 Mariana Aparecida Vilmondes Türke

Human Rights and eXtractive industries in Latin America: What Responsibility of CORPORATIONS AND THEIR STATES OF ORIGIN FOR HUMAN RIGHTS VIOLATIONS IN THE INTER-American Human Rights System?.

Alberto do Amaral Junior e Viviana Palacio Revello

MultinaCiOnAIS FAST FASHION E DIREITOS HUMANOS: EM BUSCA DE NOVOS PADRÕES DE RESPONSABILIZAÇÃO 255

Laura Germano Matos e João Luis Nogueira Matias

III. Artigos sobre outros temas

EFFICIENCY AND EFFICACY OF PUBLIC FOOD PROCUREMENT FROM FAMILY FARMERS FOR SCHOOL FEEDING IN BRAZIL. 271

Rozane Márcia Triches 
A relaÇão ENTRE O GRAU de INTEGRaÇÃo ECONÔMiCA E O SISTEMA DE SOLUÇÃo DE CONTROvÉRSIAS: UM ESTUdo COMPARATIVO ENTRE A UNIÃo EURopeia E O MERCOSUl.....................286

Luciane Klein Vieira e Elisa Arruda

THE RIGHTS TO MEMORY AND TRUTH IN THE INTER-AMERICAN PARADIGMS OF TRANSITIONAL JUSTICE: THE CASES OF BRAZIL AND CHILE 308

Bruno Galindo

Juliana Passos de Castro

A margem nacional de apreciação na Corte Interamericana de Direitos Humanos.325 Gilberto Schäfer, José Eduardo Aidikaitis Previdellie e Jesus Tupã Silveira Gomes

Novos Direitos FUNDAMENTAIS NO ÂMBITo DA UNASUL: ANÁLISE DAS AGENDAS DE Brasil E VENEZUELA À LUZ DO DIREITO À PAZ.

Pedro Pulzatto Peruzzo e Arthur Ciciliati Spada

A atuação do Grupo Mercado Comum frente À Criminalidade organizada transnacio-

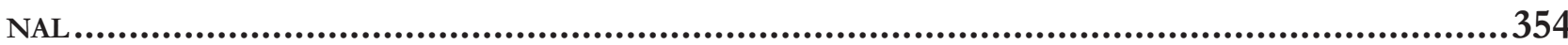

Sabrina Cunha Kesikowski, Luis Alexandre Carta Winter e Eduardo Biacchi Gomes

COUNTER-TERRORISM LEGISLATION AND TERRORIST ATTACKS: DOES HUMAN RIGHTS HAVE SPACE?

Heloisa Tenello Bretas e Daniel Damásio Borges

Territórios da ViolênCia de GÊNERo: NORMATIVA INTERNACIONAL E os Casos "CAMpo AlGodoeiro” (MÉXICO) - “Morro do Garrote” (BrasiL)

Eugênia Nogueira do Rêgo Monteiro Villa e Bruno Amaral Machado

O USO DE MECANISMOS INFORMAIS DE GOVERNANÇA GLOBAL E SUA APLICABILIDADE NAS LICITAÇÕES PÚBLICAS BRASILEIRAS.

Fabiano de Figueiredo Araujo e Paulo Afonso Cavichioli Carmona

Autonomia INSTITUCIONAL DA IGREJA CATÓliCA E A INGERÊNCIA INDEVIDA DO ESTADO BRASILEIRo POR EVENTUAIS Ilícitos CANÔNicos: ANÁlise do CASO de Formosa-GO, À luz do TraTADo Brasil-Santa SÉ de 2010 
A MORE TARGETED APPROACH TO FOREIGN DIRECT INVESTMENT: THE ESTABLISHMENT OF SCREENING SYSTEMS ON NATIONAL SECURITY GROUNDS

Carlos Esplugues Mota

IV. RESENHAS 467

Direito Internacional em Perspectiva Transcivilizacional de Yasuaki Onuma........469 Arthur Roberto Capella Giannattasio

Resenha do livro Space, Global Life: The Everyday Operation of International LaW and Development, de Luis Eslava .473

Matheus Gobbato Leichtweis

QUEM TEM MEDO DO PÓS-COLONIAL NO DIREITO INTERNACIONAL? UMA RESENHA DE "DECOLONISING INTERNATIONAL LAW: DEVELOPMENT, ECONOMIC GROWTH AND THE POLITICS OF UNIVERSAlity" de Sundhya Pahuja

Gabriel Antonio Silveira Mantelli

Direitos humanos COMO UM NOVO PROJETO PARA O Direito INTERNACIONAL? Notas sobre The Last Utopia, de Samuel Moyn .490 João Roriz 


\title{
The rights to memory and truth in the inter- american paradigms of transitional justice: the cases of Brazil and Chile*
}

\author{
Os direitos à memória e à verdade nos \\ paradigmas interamericanos da justiça de \\ transição: os casos do Brasil e do Chile
}

\author{
Bruno Galindo** \\ Juliana Passos de Castro***
}

\begin{abstract}
The paper deals with the rights of society to the truth and the memory regarding serious violations of human rights during authoritarian regimes. To do so, the legal parameters of transitional justice established by the jurisprudence of the Inter-American Court of Human Rights and, from them, the methods of comparative law are used, directing the analysis to a comparison between the experiences of commissions of truth and memory in Brazil and Chile, observing their positive and negative points, based on the established objectives to favour the consolidation of a democratic State with rule of law where the knowledge and memory of the truth can avoid new authoritarian regimes. With this objective, a qualitative research was carried out on the truth commissions established by official initiative in Brazil and Chile, from their official reports. The obtained results relate to the verification of the level at which these countries are in terms of concretization of memory and truth, based on the parameters of the Inter-American System, considering the advances made and the gaps still present.
\end{abstract}

Keywords: Brazil. Chile. Memory and truth. Transitional justice. InterAmerican System.

* Recebido em 30/01/2018

Aprovado em 26/04/2018

** Professor Associado da Faculdade de Direito do Recife/Universidade Federal de Pernambuco (UFPE); Doutor em Direito pela UFPE/Universidade de Coimbra-Portugal (PDEE); Conselheiro Estadual e Presidente da Comissão de Direitos Humanos da OAB/PE. E-mail: brunogalindoufpe@gmail.com

*** Doutoranda em Direito na Universidade Federal de Pernambuco (UFPE); Mestra em Direito pela UFPE.

E-mail: julianapassosdecastro@gmail.com

\section{Resumo}

O artigo trata dos direitos da sociedade à verdade e à memória quanto às graves violações dos direitos humanos durante regimes autoritários. Para tanto, utiliza-se os parâmetros legais da justiça de transição estabelecidos pela jurisprudência da Corte Interamericana de Direitos Humanos e, a partir deles, os métodos de direito comparado, direcionando a análise a uma comparação entre as experiências de comissões de verdade e memória no Brasil e no Chile, observando seus pontos positivos e negativos, a partir dos objetivos estabelecidos para favorecer a consolidação de um Estado democrático de direito onde o conhecimento e a memória da verdade possam evitar novos regimes autoritários. Com este objetivo, foi realizada pesquisa qualitativa sobre as comissões da verdade estabelecidas por inciativa estatal 
no Brasil e no Chile a partir de seus relatórios oficiais. Os resultados obtidos dizem respeito à constatação do nível em que se encontram os referidos países em termos de concretização de memória e verdade a partir dos parâmetros do Sistema Interamericano, considerando os avanços obtidos e as lacunas ainda presentes.

Palavras-chave: Brasil. Chile. Memória e Verdade. Justiça de transição. Sistema Interamericano.

\section{INTRODUCTION}

In the democratic political regime that emerges after a dictatorial period, the role that transitional justice plays seems fundamental in building a humanistic legal and social culture and in enhancing the democratic rule of law. The greatest success in reaching the objectives advocated by the theory of transitional justice, namely, material justice, reparation to victims, institutional reforms, clarification of the truth and creation of collective memory regarding the authoritarian period, is usually associated with greater stability of the democracy and the rule of law in those countries and the political refusal to autocratic solutions ${ }^{1}$.

For this purpose, what have become known as rights to memory and truth have special relevance from a cultural point of view, since to know and recall the authoritarian past are ways of reflecting on it, which has allowed the historical reduction of possibilities of repetition authoritarianism, and dictatorships when such rights exert themselves more strongly in the post-dictatorial context, as can be seen in a variety of cases such as post-Nazi and post-reunification Germany, post-apartheid South Africa, and several Latin American countries which became democracies again, after the military dictatorships that arose in the $60 \mathrm{~s}$ and 70 s of the last century ${ }^{2}$.

The main idea of this essay is to reflect specifically

1 GALINDO, Bruno. Democracia constitucional, justiça transicional e passado autoritário: entre a superação e o "esquecimento". In: MONTEIRO, Roberta Corrêa Araújo; ROSA, André Vicente Pires (Orgs.). Direito constitucional: os desafios contemporâneos (uma homenagem ao Professor Ivo Dantas). Curitiba: Juruá, 2012. p. 197. 2 GALINDO, Bruno. Democracia constitucional, justiça transicional e passado autoritário: entre a superação e o "esquecimento". In: MONTEIRO, Roberta Corrêa Araújo; ROSA, André Vicente Pires (Orgs.). Direito constitucional: os desafios contemporâneos (uma homenagem ao Professor Ivo Dantas). Curitiba: Juruá, 2012. p. 104. on this transitional justice question, analysing the Chilean and Brazilian experiences with regard to the institution of public policies of truth and memory.

It will be sought not only to verify the presence or absence of measures of truth and memory in the general public policies. If its absence indicates the state's omission as to the duties that derive from these rights, and consequently its non-compliance, the implementation of public policies in this sense does not automatically guarantee their effectiveness.

It is necessary to verify if memory and truth reach their individual and collective dimensions, reaching reparatory and non-repetition goals regarding human rights violations. In terms of methodology, this analysis will be based on the legal paradigms consolidated by the Inter-American Court of Human Rights, using comparative law methods to draw similarities and differences between the two experiences, temporally, spatially and ideologically close to each other. It justifies the epistemological delimitation around them, as will be seen below.

\section{INTER-AMERICAN COURT OF HUMAN RIGHTS AND THE CONSTRUCTION OF PARADIGMS OF TRUTH AND MEMORY OF TRANSITIONAL JUSTICE IN LATIN AMERICA}

The Inter-American Court of Human Rights (IACHR) is the judicial body of the Inter-American System of Human Rights, and its jurisdiction reaches Brazil and Chile, since they are signatories to both the American Convention on Human Rights (ACHR) and the optional clause of compulsory jurisdiction of the IACHR (Article 62).

Regarding the right to the truth, the Inter-American Court has made several decisions that not only confirm the existence of a right that has already been raised on the international scene, but contributes to delimiting the normative provisions that underpin it.

The leading case Velásquez Rodriguez: Honduras is the first in which the Court begins to define the contours of the right to the truth. It refers to the arrest of Manfredo Velásquez, a university student, by agents of the Armed Forces of Honduras on September 12, 1981. It was carried out without a court order and Velásquez 
became soon after a political disappeared.

The case was analysed from the facts that led to the non-compliance of the ACHR by Honduras. Thus, the Court understood that the kidnapping of the victim had configured an offense against articles 4, 5 and 7 referred to above, insofar as there was an offense against the right to life, integrity and personal liberty.

In this sense, based on articles 1,1 and 2, the Court affirms that all member states are bound to respect and guarantee the rights provided for in the Convention, with an obligation to prevent and investigate all violations of human rights recognized therein, as well as to impose sanctions on those responsible and to promote reparation of victims.

Then, the Court held that non-compliance with the ACHR had occurred inasmuch as Honduras had not taken steps to clarify the whereabouts of the disappeared, nor did they identify or sanction the perpetrators of the crime.

At the same time, the Court recognized the right of the victims' relatives to know their destination, as well as the location of their remains, and this right remains in place as long as the situation of uncertainty involving disappearances persists even in the presence of legal obstacles within the country that prevent the punishment of those responsible for the crime and also when there is a change in the rulers. According to the Court, these rights must be fulfilled by the State through all means at its disposal.

Therefore, the Court recognizes in this judgment the right to the truth in relation to the relatives of disappeared persons, based on articles 1.1 and 2, which enshrine the obligation imposed on the member States of the Inter-American Human Rights System (IAHRS) to respect human rights and promote the necessary measures to ensure their guarantee, which includes investigations in the event of violations ${ }^{3}$.

Since then, the Inter-American Court has made several other judgments confirming the understanding already espoused in the aforementioned decision and deepening the scope of the right to the truth ${ }^{4}$.

3 IACHR. Inter-American Court of Human Rights. Judgment. Caso Velásquez Rodríguez vs. Honduras. San José, 1988.

4 IACHR. Inter-American Court of Human Rights. Judgment. Caso Godinez Cruz vs. Honduras. San José, 1989. IACHR. Inter-American Court of Human Rights. Judgment. Case of Castillo-Páez, v. Peru. San José, 1997. IACHR. Inter-American Court of Human Rights.
It deserves attention the case of Barrios Altos. Peru, in which the Court addresses in more detail the fundamentals of the right to the truth.

The case involves the execution of fifteen people and the injuries in four others by the Peruvian Army in the Region of Barrios Altos, in the city of Lima.

According to the complaint, on November 3, 1981, six unidentified officers went to the scene, forced the victims to fall to the ground and committed summary execution against them.

After appeals and hearings in the domestic judicial sphere of Peru, the case ends up reaching the Inter-American Court. The Court concluded that the victi$\mathrm{ms}$ and their families were prevented from knowing the facts of the crime and pronounced on the right to the truth, stating that it is subsumed in the right of the victims or relatives to obtain from the competent authorities to clarify the facts and the corresponding responsibility through the investigation and the judgment provided for in articles 8 and 25 of the Convention.

Although the judgment does not explicitly recognize the collective dimension of the right to the truth, it represents an advance in the field of its application, extending the initial conception of that the right to truth would be related to cases of forced disappearance. In this case, it is possible to understand that the Court expresses itself in the sense that it is a right applicable to any serious violation of human rights. It also links the right to truth with other rights, such as the right to information and effective judicial protection. It considers, therefore, that the right to judicial protection is procedural in relation to the right to the truth, since it is through it that the facts and circumstances that have resulted in violation of human rights can be clarified in the judicial process ${ }^{5}$.

Another relevant decision was made in case Tibi. Ecuador. This judgment refers to Daniel Tibi, arrested in September 1995 by police officers and taken to a prison where he was subjected to torture in order to provide information on a crime of drug trafficking, which he allegedly was part of.

In that decision, the Court reaffirms the right to the truth and asserts that it understands the knowledge

Judgment. Caso Bámaca Velásquez, vs. Guatemala. San José, 2000.

5 IACHR. Inter-American Court of Human Rights. Judgment. Case of Barrios Altos v. Peru. San José, 2001. 
about the authorship of the crimes. In addition, it states that it has been developed by international human rights law and can be an important means of redress. The Judgment also condemns Ecuador to investigate the facts and make public the results of the investigations, pointing to the collective dimension of the right to the truth .

In another case, Myrna Mack vs. Guatemala, the Court refers more directly to the collective dimension of the right to the truth. This is the extrajudicial execution of Myrna Mack, in September 1990, by Guatemalan authorities. At the time, the Court stated that every person, victim, family and society has the right to know about what has happened regarding human rights violations ${ }^{7}$.

In the case Goiburú et al. vs. Paraguay, Inter-American Court reaffirms the law as one of the means of ensuring reparation to the relatives of the victims. In this sense, the Court lists the right to the truth as a dimension of reparation for immaterial damage. It also alludes to the historical truth in valuing the creation of a commission of truth and archives. The case involved illegal arrests, torture and forced disappearances promoted by Paraguay against the victims in the case ${ }^{8}$.

Related to Brazil, the case Gomes Lund et al. vs. Brazil refers to the disappearance of people in the context of the Araguaia Guerrilla. Brazil was convicted of the arbitrary detention, torture and forced disappearance of 70 people, including members of the Communist Party of Brazil and peasants in the Araguaia region in the south of the State of Pará between 1972 and 1975. On that occasion, the Court reaffirms the importance of establishing a truth commission to investigate and elucidate the facts? .

Thus, the Inter-American Court is in the sense that the right to the truth applies in any cases of enforced disappearances, whether they result in death or not, and in relation to other violations of human rights. It is also possible to deduce the existence of this right, from a

6 IACHR. Inter-American Court of Human Rights. Judgment. Caso Tibi vs. Ecuador. San José, 2004.

7 IACHR. Inter-American Court of Human Rights. Judgment. Caso Myrna Mack Chang vs. Guatemala. San José, 2003.

8 IACHR. Inter-American Court of Human Rights. Judgment. Caso Goiburú e outros vs. Paraguai. San José, 2006.

9 IACHR. Inter-American Court of Human Rights. Judgment. Caso Gomes Lund e outros ("guerrilha do Araguaia") vs. Brasil. San José, 2010. normative point of view, at the local level, depending on the national legal order.

In Brazilian case, due to the material opening clause contained in article 5, paragraph 2, of the Constitution, it is possible to recognize other implicit fundamental rights, in addition to those expressly enshrined in the constitutional text. ${ }^{10}$ In this sense, based on principles such as democracy, human dignity and publicity, as well as fundamental rights to information and freedom of expression, it is possible to affirm that the right to the truth is an implicit fundamental right in Brazilian constitutionalism.

In general, truth clarification and memory preservation are considered as important measures capable of preventing the social and historical impunity of agents who violate human rights ${ }^{11}$. Its purpose also concerns the attempt to help prevent the repetition of abuses committed by raising awareness among present and future generations ${ }^{12}$. In addition, knowledge of the truth about crimes of the past helps in the implementation of other measures, such as financial reparation for those who have suffered persecution, the construction of a file that allows eventual judgments, institutional and political reforms and the implementation of measures related to memory of the victims ${ }^{13}$.

As stated, the right to know the truth can be considered as an aspect of broad access to justice. It is also considered a dimension of the reparation measure, which is not restricted to financial compensation, insofar as it provides the victims and their families with knowledge about the facts that occurred to them ${ }^{14}$.

In this essay, it is also possible to understand it as a necessary right for the realization of the right to memory.

10 "The rights and guarantees expressed in this Constitution do not exclude others arising from the regime and the principles adopted by it, or from international treaties to which the Federative Republic of Brazil is a party."

11 LIRA, Elizabeth. Las resistencias de la memoria: olvidos jurídicos y memorias sociales. In: VINYES, Ricard (Org.). El Estado y la memoria: gobiernos y ciudadanos frente a los traumas de la historia. Buenos Aires: Del Nuevo Extremo: RBA, 2009. p. 105.

12 JELIN, Elizabeth: Quiéns? Cuándo? Para qué? actores y escenários de las memorias. In: VINYES, Ricard (Org.). El Estado y la memoria: gobiernos y ciudadanos frente a los traumas de la historia. Buenos Aires: Del Nuevo Extremo: RBA, 2009. p. 119.

13 HAYNER, Priscilla. Verdades innombrables: el reto de las comisiones de la verdad. México: Fondo de Cultura Económica, 2008. p. 226.

14 INSTITUTO Nacional de Derechos Humanos, 2011. p. 269289. 
Analysing the cases involving human rights violations, the Court has referred to the theme in order to determine that countries adopt measures for the preservation of victims' memory as a part of reparation as well as historical memory.

In the understanding of the Court, the right to memory has these two dimensions. The individual dimension refers to the reparation provided to the victims from measures of memory and the collective dimension is verified from the adoption of these measures in order to preserve the historical memory of the human rights violations that occurred. With regard to historical memory, attempts to avoid repetition are included among its purposes.

These distinctions are clear in the Anzualdo Castro. Peru trial, in which the Inter-American Court has ruled that the construction of the Museum of Memory, despite being important for the preservation of historical memory and as a measure of non-repetition, did not meet the objectives of individual memory satisfaction, ordering actions in this regard ${ }^{15}$.

Regarding the dimension of memory as reparation, the Court's understanding goes beyond the idea of recovering the suffered losses from financial compensation. This reasoning was gradually consolidated in its jurisprudence.

In Velásquez Rodríguez. Honduras, the Court recognizes the State's duty to compensate victims for violating their rights ${ }^{16}$. In the case Aloeboete, et al. Suriname, the Court notes that there are other types of reparation measures that go beyond the pecuniary modality. ${ }^{17}$

In the same sense, in Loyoza Tamyo. Peru, in the opinion of Judge Cançado Trindade, it highlights the fact that human needs reach dimensions that go beyond pecuniary reparations, and even more important that they be shaped in other ways ${ }^{18}$. In Benavides Cevallos. Ecuador, in accepting the agreement made between the State and the families of the victims, the Court protected the adoption of measures of memory as means

15 IACHR. Inter-American Court of Human Rights. Judgment. Caso Anzualdo Castro vs. Perú. San José, 2009.

16 IACHR. Inter-American Court of Human Rights. Judgment. Caso Velásquez Rodríguez vs. Honduras. San José, 1988.

17 IACHR. Inter-American Court of Human Rights. Judgment. Caso Aloeboetoe y otros vs. Surinam. San José, 1993.

18 IACHR. Inter-American Court of Human Rights. Judgment. Caso Loayza Tamayo vs. Perú. San José, 1998. of reparation. On that occasion, the State assumed the duty to include the name of Benavides Cevalles in streets, squares and schools ${ }^{19}$.

In Villagrán Morales, et al. Guatemala ("Children on the Street"), Inter-American Court ruled on the international responsibility of Guatemala regarding the detention and murder of several persons. In the decision, the Court provides that the moral damages suffered by the victims must be repaired by carrying out public works and acts that reconstitute the dignity of the victims and preserve their memory. The Judgment determines to Guatemala the designation of an educational centre with a name alluding to the young victims, in order to contribute to awakening the collective conscience and avoiding the repetition of the injurious facts, as well as preserving the memories of the victims ${ }^{20}$.

\section{Research commissions in Chile and BRAZIL: ANALYSIS FROM THE INTER-AMERICAN PARADIGMS OF TRANSITIONAL JUSTICE}

In relation to the Brazilian and Chilean cases, the temporal gap between the democratic transition and the institution of investigative commissions is a first difference that characterizes the process of searching for truth about the human rights violations that occurred in their dictatorships.

In Chile, investigations into the serious violations of human rights occurred during the exception regime led by General Augusto Pinochet were initiated from a truth commission, the Rettig Commission, a process that continued with the establishment of the Valech I and II Commissions. The National Repair Corporation, although it also had other purposes related to the implementation of remedial measures and assistance to victims, according to recommendations of the Rettig Commission also had attributions under the terms of the National Truth and Reconciliation Commission, continuing its work, producing a report at the end. The Board of Dialogue, in turn, despite having some investigative powers, acted in a more restricted way, in the

19 IACHR. Inter-American Court of Human Rights. Judgment. Caso Benavides Cevallos vs. Ecuador. San José, 1998.

20 IACHR. Inter-American Court of Human Rights. Judgment. Caso de los "Niños de la Calle" (Villagrán Morales y otros) vs. Guatemala. San José, 2001. 
sense of identifying the destination and remains of the disappeared. In spite of this, the clarification of the truth was still its founding axis.

Another aspect that deserves mention is the dimension of transitional justice, which guided the first initiatives to combat abuses committed during the authoritarian period. In the case of Chile, the chosen axis was truth and reparation for purposes of reconciliation. The Decree creating the first Commission and the reports of the others emphasized the importance of truth as a first step towards adopting other measures ${ }^{21}$.

José Zalaquett, a professor at the University of Chile and a member of the Rettig Commission, stresses that the objectives of any transitional policy must be reparation and prevention, and to be legitimate, such policies must be based on the truth about what happened and democratically adopted ${ }^{22}$.

The first measures of reparation were derived from the recommendations of the Rettig Commission and implemented through 19,123 Act. They included, among other measures, financial reparations to the victims of the violence practiced during the military dictatorship.

In Brazilian case, transitional justice was initiated from the reparatory axis, and, only secondarily, the first measures of truth and memory were reached. In spite of the invaluable work in the military justice processes carried out by the researchers coordinated by Paulo Evaristo Arns, Cardinal Archbishop of São Paulo, and published in 1985 under the title "Brazil: Never More", only in 1995 did we have the first major initiative in the transitional justice field, which was 9140/1995 Act and the subsequent creation of the Special Committee on the Death and Disappearance of Persons.

That Act recognizes as dead 136 people, ruling the situation of absence and granting compensation to family members. The creation of the Political Deaths and Disappearances Commission, according to the provisions of the same Act, functions as a first commission

21 HITE, Katherine; COLLINS, Cath. Memorial fragments, monumental silences and reawakenings in 21-st century Chile. Millenium: Journal of International Studies, v. 38, n. 2, p. 379-400, 2009.

22 ZALAQUETT, José. Derechos humanos e limitaciones políticas en las transiciones democraticas del Cone Sur. Colección Estudios Cieplan, Santiago, n. 33, p. 147-186, 1991. SIKKINK, Kathryn; WALLING, Carrie Booth. The impact of human rights trials in Latin America. Journal of Peace Research, v. 44, n. 4, p. 427-445, 2007. with investigative characteristics, but cannot be classified as a truth commission in the strict sense.

The Commission had no legal powers in relation to the investigation of facts, nor finding the truth about human rights violations and identifying of those responsible for them. Although the recognition of the disappearance of persons not listed in Annex I to the Act had been conferred to the Commission, it would be possible to make efforts to locate bodies only when there were indications of where they could be found.

Thus, the duty to search for missing persons was first and foremost for victims' relatives, who should instruct the petitioners with all the necessary evidence to clarify that the death or disappearance occurred because of political persecution. This was an aspect of the Act that suffered many critics ${ }^{23}$. It was argued that it was Brazil's duty to locate the disappeared, since it would be responsible for what happened, and should allow, for example, access to the archives of the Armed Forces, in which like relevant information would probably be found.

Both 9140/1995 Act and the Special Commission of the Dead and Disappeared were important in the process of Brazilian redemocratization, in view of coming from the first Brazilian government initiative to assume responsibility for the deaths of political disappeared persons, and also to pay compensation to the victims or to their families. However, such measures were insufficient for the clarification of the truth and the preservation of the memory of the events occurred during the period of exception.

The work of the Special Commission on the Death and Disappearance of Persons in Missing Persons was published in a report identifying the victims and acknowledging the violations they suffered. Therefore, as reported in the document published by the Secretariat of Human Rights, there was no collaboration of the Federal Police or the Armed Forces ${ }^{24}$.

The investigations were made only to verify the deaths and disappearances that occurred for reasons of po-

23 SANTOS, Sheila Cristina. A comissão especial sobre mortos e desaparecidos políticos e a reparação do Estado às vítimas da ditadura militar no Brasil. 2008. Dissertation (Masters) - Pontifícia Universidade Católica de São Paulo, São Paulo, 2008. p. 146.

24 SECRETARIA ESPECIAL DOS DIREITOS HUMANOS. Direito à verdade e à memória: comissão especial sobre mortos e desaparecidos políticos. Brasília, 2007. p. 39. 
litical persecution. There was no identification of those responsible and no description of individual acts. Despite the publication of the Report, many cases of state violence continued without clarification. Although there were recognition of the deaths of some disappeared people due to the repression of the period, few bodies were located and identified when the book entitled Right to Memory and Truth was published.

The Amnesty Commission, in turn, was also created from the financial reparation axis. However, in its task of assessing the requests for amnesty and compensation made by the political persecuted people, it also assumed a perspective of clarification of the truth inasmuch as it has constituted a collection on the victims' reports regarding their experiences, as well as the documents brought by them, hitherto unknown. The Commission's analysis of the requests for amnesty and reparations has consolidated itself as a space for the victims' narrative and a collection of documents on the suffered repression, contributing to a record on human rights violations practiced by the State. Through its activities with the Amnesty Caravans and the Brands of Memory Program, it has also contributed to the dimensions of truth and memory, a process that has allowed civil society to participate $^{25}$.

However, in addition to the Special Commission of the Dead and Disappeared and the Amnesty Commission, they do not have the legal competence to provide a comprehensive version of the facts and circumstances surrounding crimes committed during the dictatorial period, there is yet another factor that can be seen as a limitation to the effectiveness of the right to memory and truth. It is the recognition of the arbitrariness and suffering inflicted on victims as a form of moral reparation within the framework of the rights to memory and truth.

In addition to the lack of legal competence of the Commissions to investigate extensively and establish more reliable versions regarding the facts, the way in which the Brazilian transition was conducted, prioritizing the reparatory aspect in its financial perspective, ended up contributing to the depreciation of the political persecution to the extent in which the indemnities

25 BAGGIO, Roberta Camineiro. Marcas da memória: a atuação da comissão de anistia no campo das políticas públicas de transição no Brasil. Ciências Sociais da Unisinos, São Leopoldo, v. 48, n. 2, p. 111 118, may/aug. 2012. were not seen as a result of the damages suffered by them, which is evidenced by the press behaviour when referring, albeit pejoratively, to the payments made as a "bolsa ditadura"26 27.

Roberta Baggio explains that the Amnesty Commission, based on three approaches, has worked to reverse this situation, in an attempt to clarify to society the events experienced during the dictatorship.

The first approach is giving a new meaning to the act of amnesty, differently from forgetfulness. When amnesty is granted to the petitioner, even in cases where no indemnity is paid, political resistance is recognized as an act of courage, and a request for pardon is made to the victim on behalf of the State.

The second one is the oral or written account of the victims as a source of revelation of the story in a future Memorial. It is important to record the contribution of this action to the construction of historical memory, from the perspective of the victims.

Finally, the third approach is, as the author refers, the work carried out by Amnesty's Caravans, which cross the country, carrying out both actions, acquiring an educational function insofar as it involves civil society.

Despite the importance of these actions, both the gravity of human rights violations and the lack of knowledge about violence committed in the authoritarian period, as well as the elapsed time that contributed to the distancing of the facts, required the work of a truth commission with broader powers to clarify what truly occurred in the exception period.

The first commission of truth, which, at least formally, commits itself to this proposal and institutes truth and memory as the central axes of its action, despite referring consistently to national reconciliation, without making explicit the meaning it attributes to the term. It was the National Truth Commission, created by 12528/2011 Act and established in 2012, instituted 27 years after the democratic transition, considering the period post-1985. We will discuss it soon later.

26 This expression means something like permanent scholarship for victims of the dictatorship.

27 BAgGIO, Roberta Camineiro. Justiça de transição como reconhecimento: limites e possibilidades do processo brasileiro. Cadernos IHU Ideias, São Leopoldo, ano 12, v. 12, n. 208, p. 18, 2014. 


\section{Official Versions: a partial reality in BOTH COUNTRIES}

Although Chile has begun a process of clarification of the truth much earlier than Brazil, even nowadays, there is a lack of specific research on many of its aspects.

In the case of the National Truth and Reconciliation Commission, Emilio Crenzel concluded that three factors indicate the limited notion of human rights that characterized its performance ${ }^{28}$.

Firstly, the author refers to the restrictions imposed by the Decree of its creation regarding the reduction of the object of investigation to situations that have resulted in death or disappearance. As a result of this, the Rettig Report focused on addressing the circumstances surrounding disappearances and killings to the detriment of other manifestations of state violence such as torture without the result of death, exile and political imprisonment, as well as the vulnerability of social rights.

Secondly, the author states that there was no link between the political dimension and human rights violations. He argues that the Rettig Report, by practically equate the violence practiced by the state agents with that coming from opponents of the regime, as if both were on an equal footing, privileged the individual character of the violations to the detriment of the relation between social order and violence.

Third, the author points to the historical and political dissociation of violence. For him, the truth was elaborated from the logic of the culprit and the victim, disregarding the relation between political violence, economic factors and social inequality. Political violence was then explained as an effect of the local manifestation of Cold War dissent, which, in a way, justified the intervention of the Armed Forces after the coup d'état ${ }^{2}$.

28 CRENZEL, Emilio. Los derechos humanos y las políticas de la memoria: reflexiones a partir de las experiencias de las comisiones de la verdad de Argentina e Chile. In: VINYES, Ricard (Org.). El Estado y la memoria: gobiernos y ciudadanos frente a los traumas de la historia. Buenos Aires: Del Nuevo Extremo, 2009. p. 361.

29 CRENZEL, Emilio. Los derechos humanos y las políticas de la memoria: reflexiones a partir de las experiencias de las comisiones de la verdad de Argentina e Chile. In: VINYES, Ricard (Org.). El Estado y la memoria: gobiernos y ciudadanos frente a los traumas de la historia. Buenos Aires: Del Nuevo Extremo, 2009. p. 361. ACUÑA, Carlos H. Transitional justice in Argentina and Chile: a never-ending
It should be noted that, despite this, the Report expressly states that there was no justification for the perpetration of the violations.

Although the creation of this Commission was positive, as a first step taken by President Patricio Aylwin, in keeping with the characteristics of the Chilean transition, the victim organizations and human rights defenders criticized the Chilean Truth Commission for its various limitations.

In addition to the restriction on the crimes to be investigated, the Commission did not have the power to disclose the names of the perpetrators, to investigate human rights violations that did not result in death, and to require the presence or testimony of persons ${ }^{30}$. As it has been happening in Brazil, there was neither the collaboration of the Armed Forces nor the access to military documents of the dictatorial period.

The same criticisms can be attributed to the National Reparations Corporation, since it acted in the same terms as the Rettig Commission, with the difference that it also took on other responsibilities stemming from the recommendations of the first Commission on reparations.

As for the Dialogue Table, which did not really function as a Truth Commission, its objective regarding the location of political disappeared or their mortal remains has not been reached. In 2001, a list was given by the Armed Forces and Order, indicating the location of the bodies of 200 missing persons, 20 of whom were not identified.

Subsequently, it was found that most of the information was untrue, and the results achieved were not very relevant. For the National Institute of Human Rights, an example refers to the case of Juan Lins Riveira Matus. According to the Armed Forces, his mortal remains would have been thrown into the sea. However, through judicial investigations, the body was identified in the grounds of the Fuerte Arteaga ${ }^{31}$.

story? In: ELSTER, Jon (Org.). Retribution and reparation in the transition to democracy. Cambridge: University Press, 2006. p. 223.

30 CRENZEL, Emilio. Los derechos humanos y las políticas de la memoria: reflexiones a partir de las experiencias de las comisiones de la verdad de Argentina e Chile. In: VINYES, Ricard (Org.). El Estado y la memoria: gobiernos y ciudadanos frente a los traumas de la historia. Buenos Aires: Del Nuevo Extremo, 2009. p. 361.

31 INSTITUTO NACIONAL DE DERECHOS HUMANOS. Situación de los derechos humanos en Chile. Informe Anual, Santiago, p. 243-260, 2011. Available in: <http://www.indh.cl/informe 
The Valech I and II Commissions, set up to clarify cases of political imprisonment and torture and, in the case of the second, disappearances and extrajudicial executions not appreciated by the Rettig Commission and the National Corporation, were also not sufficient to cover all cases of serious violations of human rights. Issues related to gender violence, violations directed against Mapuche children and people (indigenous Chileans), were also not adequately clarified.

In addition to these questions that have not been the subject of specific investigations, there is a common problem, related to both Valech I and II, which means a major obstacle to the realization of the truth. This is article 15 of 19,992 Act, which provides for a 50-year period of secrecy of the testimonies and of all documents that were not published in the reports of the committees. The secret imposed by that Act reaches even the judiciary, which could not have access to the data.

According to information provided by the Museum of Memory and Human Rights, one of the first measures of the courts, when analysing an action involving the violations of the dictatorial period, was the sending of a letter to the institution where the files containing the results of the works, requesting the relevant documents. In the case of the Rettig Commission, the Museum responds to requests, but when it comes to the files of the Valech Commissions, the data were not made available due to legal impediment. ${ }^{32}$

Other cases also indicate the insufficiency of investigation regarding Valech's work. Thirty-four applications involving detentions abroad with the participation of the State were presented. In these situations, the Commission chose not to recognize the victims, since, to that end, it would have to identify Chilean participants in charge of the repressive apparatus, which it was not allowed to do because it could not attribute individual responsibilities. There were also allegations of detention and torture by 102 men serving in the military. The Commission did not recognize the fact that it was a victim because it was not possible to prove the political motivation. Situations involving arrest and torture for abuse of power and common crimes were also not re-

2011Inf\%20Anual\%20INDH12\%20WEB.pdf>. Access: 15 aug. 2013.

32 This data was obtained through personal contact of the second author with Maria Ortiz, head of the research sector of the Museum of Memory and Human Rights of Chile, in: nov., 2013. cognized. As regards persons detained for political reasons in private premises, the Commission considered some cases, but with a higher degree of severity than the others. This was also the case for people detained at demonstrations that suffered torture ${ }^{33}$.

Although Valech II has accumulated the attributions previously conferred on the previous commissions, it has not brought great contributions beyond the recognition of new victims. In spite of, legally, it could not cover different hypotheses of investigations, it could have shed some light on many points that came to light with Valech I's work, such as gender violence.

As regards the recognition of victims, the relationship between the number of submitted applications and the number of qualified persons is quite different, differently from previous committees. In the case of extrajudicial executions and disappearances, of the 622 cases presented, only 30 were recognized. In the case of political prisons and torture, of the 31,831 requests, only 9,795 had qualified victims, which raised many questions from civil society. Another obstacle is that it would be impossible for applicants to ask for reconsideration if their application was not accepted by the Commission $^{34}$.

In the case of Brazil, it has historically been the Amnesty Commission to play this important acknowledging role of political persecution and serious violations of human rights occurred in the military dictatorship, since its operation occurs for an indefinite period and, at least in analysis of individual cases, can recognize what the victims suffered.

There are two types of political persecution covered by $10,559 / 2002$ Act. The first is composed of persecuted politicians who have suffered violations of their public liberties and their physical integrity. The second refers to those who suffered persecutions related to professional activity during the dictatorship regime ${ }^{35}$.

Brazil also had an opportunity to advance in matters

33 COMISIÓN NACIONAL SOBRE PRISIÓN POLÍTICA Y TORTURA. Informe, 2004. p. 84-86.

34 INSTITUTO NACIONAL DE DERECHOS HUMANOS. Situación de los derechos humanos en Chile. Informe Anual, Santiago, p. 243-260, 2011. Available in: <http://www.indh.cl/informe 2011Inf $\% 20$ Anual $\% 20$ INDH12\%20WEB.pdf>. Access: 15 aug. 2013.

35 ABRÃO, Paulo. Justiça de transição no Brasil: o papel da comissão de anistia do Ministério da Justiça. Revista Anistia Política e Justiça de Transição, Brasília, p. 15-16, 2009. 
of truth and memory for the broad powers conferred on the National Truth Commission, through 12,528 / 2011 Act. This rule allowed human rights violations to be investigated to a previously non-existent extent. Working groups were formed to analyse specific issues, such as gender violence, violence against the military prosecuted by regime, against workers and participants in the trade union movement, against peasants and indigenous people.

According to Marlon Weichert, if, on the one hand, the temporal distance between the political transition and the installation of the National Truth Commission in Brazil has caused problems access to supporting documents and reparation of victims, on the other hand, the distancing of the political disputes that gave rise to the risk of retreat would allow a broader understanding of the conditions that led to the establishment of the authoritarian regime and to human rights violations ${ }^{36}$.

In December 2014, the National Truth Commission published its Report after just over two and a half years of work.

It is possible to identify important contributions from the Commission regarding the realization of the right to the truth in Brazil.

The NTC concluded that the serious violations of human rights practiced by Brazil, especially during the period of dictatorship, were a systematic practice, used as a government policy to eliminate opponents of the military regime then in force. State violence, therefore, did not consist of isolated acts. According to the Commission, this pattern of violence continues to be practiced by the security forces, due to the lack of investigation and punishment of the guilty ${ }^{37}$.

Some important points have also been clarified. One of them was the confirmation of Brazil's participation, with US support, in Condor Operation, a network of foreign cooperation with countries of the Southern Cone (Argentina, Bolivia, Chile, Paraguay and Uruguay) to support the persecution of political dissidents ${ }^{38}$.

36 WEICH, Marlon Alberto Weichert. A comissão nacional da verdade. In: SILVA FILHO, José Carlos Moreira; TORELLY, Marcelo Dalmás; ABRÃO, Paulo (Orgs.). Justiça de transição nas Américas: olhares interdisciplinares, fundamentos e padrões de efetivação. Belo Horizonte: Fórum, 2013. p. 161-180.

37 COMISSÃO NACIONAL DA VERDADE. Relatório, ano 3, v. 1, 2014. Available in: <www.cnv.gov.br>. Access: 23 sept. 2015. p. $962-964$.

38 COMISSÃO NACIONAL DA VERDADE. Relatório, ano 3,
Another relevant point was the approach of the judiciary, especially the Supreme Court, during the military dictatorship. The CNV found that the Supreme Court acted based on Institutional Act 5, ignoring allegations of torture and denying habeas corpus to opponents of the regime ${ }^{39}$. Also worthy of mention is the identification of 230 sites used for the practice of human rights violations, including military units, clandestine sites and ships $^{40} .377$ authors of human rights violations have also been identified ${ }^{41}$.

The Commission also made important recommendations to be followed by the Brazilian State ${ }^{42}$. It suggested that perpetrators of crimes against humanity should be criminally liable and have exercised the right of compensation from the people who gave cause to the payment of indemnities by the government. Institutional reforms have also been mentioned. Among them, the demilitarization of the police, the increase of organs for the protection of human rights, especially the prevention and combat of torture, extinction of state military justice, repeal of the National Security Act, revelation of the truth, with the monitoring by the State, of the recommendations made by the Commission and continuity in the work of opening the archives, reparation of victims and adoption of measures of memory.

It is necessary, however, to point out some shortcomings in the Commission's activities, which go beyond formal questions and concern the investigations and clarification of the truth and indicate the incompleteness of the investigation of the facts.

There was no indication of the names of alleged perpetrators of torture and illegal arrests that did not result in enforced disappearance or death. Cases of political imprisonment and torture have also not been quantified.

v. 1, 2014. Available in: <www.cnv.gov.br>. Access: 23 sept. 2015. p. $175-250$.

39 COMISSÃO NACIONAL DA VERDADE. Relatório, ano 3, v. 1, 2014. Available in: <www.cnv.gov.br>. Access: 23 sept. 2015. p. $933-958$.

40 COMISSÃO NACIONAL DA VERDADE. Relatório, ano 3, v. 1, 2014. Available in: <www.cnv.gov.br>. Access: 23 sept. 2015. p. 727-823.

41 COMISSÃO NACIONAL DA VERDADE. Relatório, ano 3, v. 1, 2014. Available in: <www.cnv.gov.br>. Access: 23 sept. 2015. p. 841-932.

42 COMISSÃO NACIONAL DA VERDADE. Relatório, ano 3, v. 1, 2014. Available in: <www.cnv.gov.br>. Access: 23 sept. 2015. p. $964-975$. 
As Chilean case, situations such as those of exiles were not faced, nor was there any significant advance in the search for the mortal remains of the political disappeared. Although working groups have been set up to analyse violence against specific social segments, there has been no detailed analysis of these issues. By way of example, vol. 2 of the Report, which brings thematic texts in relation to them, deals with the entire indigenous question in all its complexity in only 60 pages; the issue of homosexuality is dealt with in a 13-page text and there is no specific thematic text on violence against women, despite the numerous reports of rape and torture that are characterized by specifically exploiting the female condition ${ }^{43}$.

\section{Official truths and public policies of MEMORY}

The public policies of memorials reflect the various dilemmas related to the dimension of enlightened truth in Chile.

The Human Rights Program of the Ministry of the Interior, responsible for the projects related to memory spaces has included, in most cases, memorials involving the victims of homicides and political disappearances. In its official publication, only one of them pays homage to the women victims of the dictatorship. This memorial, currently, is in very poor state of conservation. No memorial has been identified in honor of the tortured, although there have been recommendations in this sense by the Valech Commission.

The Program usually operates from the initiative of the family groups, granting financial support for its creation or maintenance. Therefore, there is no structured action plan for the remembrance of all victims.

Another public policy of memory in Chile consists of the Museum of Memory and Human Rights. As already mentioned, this Museum corresponds to an important space of preservation of the historical and individual memory of the victims. Also as a document archive, this institution plays an important role. An example of this is the requests made by the Chilean judiciary to obtain information that is available for the investigation of legal proceedings. Its importance

43 CNV, Report, v. 2. is also reflected in the educational field, especially since there is no official policy in this regard. Many schools, therefore, have conducted guided tours with students and teachers, and there are trainings for teachers on the theme of this Museum.

It is also a space where the victims are remembered, and there are ceremonies in which they are paid homage. The data preserved by the Museum serve as support for research on the subject, through its availability in the documentation centre ${ }^{44}$.

Nevertheless, it should be noted that the memory programs developed in the Museum are based on the reports issued by the Rettig and Valech Commissions. On the one hand, the importance of an official narrative recognized by the State, about its past of violence, remains evident. On the other hand, it also means the reflection of the partial elaborations of truth.

Another issue concerns the inexistence of specific memory space for victims of sexual violence, against minors and the Mapuche people. Although the Valech Commission has addressed the issue of sexual violence, and given greater visibility to the subject, there is no specific official truth for each case.

It should be noted that in Brazil, the Amnesty Commission, in addition to the contributions to truth and memory already mentioned, has been a constant space for victims' testimony, which can be publicly provided. This measure is a way of preserving the memory of the violence suffered by them, from their own gaze. A form of symbolic reparation that reaches memory in its individual dimension is then verified, based on the recognition of the suffering of political persecution ${ }^{45}$. There are also contributions to memory in its collective dimension, considering the publicity of testimonies, which can be enhanced through the way they will be narrated in other public spaces or inserted in other public policies of memory.

As for the National Truth Commission's action on the right to memory, it was somewhat economic. In

44 HITE, Katherine; COLLINS, Cath. Memorial fragments, monumental silences and reawakenings in 21 -st century Chile. Millenium: Journal of International Studies, v. 38, n. 2, p. 398-399, 2009.

45 OLIVEIRA, Roberta Cunha; SILVA FILHO, José Carlos Moreira. Os testemunhos das vítimas e o diálogo transgeracional: o lugar do testemunho na transição pós-ditadura civil-militar brasileira. In: MEYER, Peluso Neder; OLIVEIRA, Marcelo Andrade Cattoni (Orgs.). Justiça de transição nos 25 anos de Constituição. 2. ed. Belo Horizonte: Initia, 2014. p. 301-343. 
Chapter 18, referring to its recommendations, it addresses the issue only half a page, basically stating that measures should be taken to preserve the memory of the grave human rights violations that occurred during the period, as well as of its victims. To this end, it proposes that Brazil must preserve, restore and promote the tombamento ${ }^{46}$ or creation of memory marks in urban or rural properties where these violations occurred; to institute and install in Brasilia a Museum of Memory; repeal measures to honour perpetrators of the grave violations of human rights of the period, in particular by removing honoraria granted to them, as well as by promoting the change of the name of public places, buildings, transportation routes and public institutions that refer to public or private agents who have been known to be involved in such violations ${ }^{47}$.

\section{THE SERIOUSNESS OF HUMAN RIGHTS VIOLATIONS AND THE FULFILMENT OF THE RIGHT TO MEMORY AND TRUTH AS A GOAL OF NON- REPETITION}

In Chile, since the transition to democracy, clarifying the truth and building a memory of past atrocities have reflected conflicts between opposition groups and those that supported the former military government.

These dilemmas have been observed recently, as a result of some facts that demonstrate the divergent perceptions of society about the past of repression. ${ }^{48} \mathrm{In}$ 2010, for example, there were requests from the Catholic Church for the Chilean executive to grant pardon to military personnel who committed crimes to a lesser degree and who showed regret, an act widely disputed by human rights defenders, on the grounds that such a

46 Administrative measure provided for in Brazilian law for the preservation of goods of great historical and cultural value.

47 COMISSÃO NACIONAL DA VERDADE. Relatório, ano 3, v. 1, 2014. Available in:<www.cnv.gov.br>. Access: 23 sept. 2015. p. 974.

48 Still on the disputes for memory, Steve Stern in his book Luchando por mentes y corazones: las Batallas de la memoria en el Chile de Pinochet, analyses that even during the dictatorship there was a dispute of memory in order to consolidate a positive vision of the dictatorship and another in the sense of not accepting the abuses that had been occurring The struggles for memory in the period corresponding to the validity of the dictatorship will not be analysed in the present work (STERN, Steve J. Luchando por mentes y corazones: las batallas de la memoria en el Chile de Pinochet. Santiago: Universidad Diego Portales, 2009.). measure would not prevent the atrocities of the past ${ }^{49}$.

According to the National Institute of Human Rights, in 2011, the National Education Council tried to replace the term military dictatorship by military regime in the program of the sixth basic year, on the grounds that there should be greater clarification as to the reasons that led to the adoption of the political regime ${ }^{50}$. However, due to the criticisms directed against the measure, the Ministry of Education maintained the traditional nomenclature, which is military dictatorship, as well as the expression military regime.

On June 10, 2012, the September 11 Corporation paid tribute to Augusto Pinochet at the Caupolicán Theater in Santiago. These honours of actors who violated human rights contribute to the denial or justification of crimes against humanity, and are confronted with the construction of a memory of repudiation of these events.

Although there are deficits regarding the dimensions of memory and truth, in the case of Chile, the general structure of repression has been known and disseminated by virtue of the work of the Commissions of Truth and memory spaces. Even conservative sectors, such as the Armed Forces, recognised the seriousness of the human rights violations experienced by the country, and the Judiciary broadly adopted the thesis consolidated in the Inter-American Court in the Almonacid Arellano vs. Chile in relation to the criminal responsibility of the perpetrators..$^{51} 52$

Nevertheless, the above-mentioned facts are examples of manifestations that extol the violence of the

49 IGREJA Católica do Chile propõe perdoar crimes de militares da ditadura. Euronews. Available in: <http://pt.euronews. com/2010/07/22/igreja-catolica-do-chile-prope-perdoar-crimesde-militares-da-ditadura/>. Access: 21 sept. 2013.

50 INSTITUTO NACIONAL DE DERECHOS HUMANOS. Situación de los derechos humanos en Chile. Informe Anual, Santiago, p. 83-121, 2011. Available in: <http://www.indh.cl/informe 2011/ Inf\%20Anual\%20INDH12\%20WEB.pdf>. Access: 15 aug. 2013. 51 IACHR. Inter-American Court of Human Rights. Judgment. Caso Almonacid Arellano e outros vs. Chile. San José, 2006.

52 FERNÁNDEZ, Karinna Neira. La jurisprudencia de la Corte Suprema Chilena, frente a las graves violaciones contra los derechos humanos cometidos durante la dictadura militar. In: GOMES, Luiz Flávio; MAZZUOLI, Valério de Oliveira (Orgs.). Crimes da ditadura militar: uma análise à luz da jurisprudência atual da Corte Interamericana de direitos humanos. São Paulo: Revista dos Tribunais, 2011. p. 289; GALINDO, Bruno. Justiça de transição na América do Sul: possíveis lições da Argentina e do Chile ao processo constitucional de transição no Brasil. In: FEITOSA, Enoque et al. (Orgs.). O judiciário e o discurso dos direitos humanos. Recife: UFPE, 2012. p. 225-229. 
country's dictatorial past. In Chile, the reconstruction of a democratic coexistence based on the memories of a past of institutional violence still occurs in parallel with a favourable reading by the civil society regarding the type of regime established in the period of authoritarianism.

In Brazil, despite the work of the CNV and the scholars and pro-justice transitional agents that preceded it, there is a great precariousness in the perception of the harms of a dictatorial regime, being, in fact, a practically unique case in Latin America of a country that has never punished any criminal against the humanity of the period in view of the interpretation traditionally given to the so-called Amnesty Law, corroborated by the Supreme Court in 2010, despite frontally contradicting the consolidated jurisprudence of the Inter-American Court, including the Gomes Lund Case in which Brazil was condemned, also in 2010.

This is inevitably reflected in the realization of the rights to truth and memory, with frequent criticisms of the CNV that it would be a "half-truth" commission, which would be practicing "revenge", as well as the exaltation of the dictators of the period as "heroes that saved Brazil from communism" and that the dictatorship would be justified because it was to avoid a greater evil. One of the most emblematic of this recent situation was the pronouncement by Federal Deputy Jair Bolsonaro, in a national network, on the occasion of the impeachment process of former President Dilma Roussef, in April 2016. In justifying his vote in favour of the openness of the process, he paid tribute to the late Colonel Carlos Alberto Brilhante Ustra, the first military recognized in two judicial instances as a torturer in the period of the military dictatorship, ${ }^{53}$ being celebrated by the parliamentarian as the "terror of Dilma Roussef", in a probable allusion to the tortures suffered by former President, who was in the custody of the Brazilian State in the period, and was a victim of these acts in sessions led by Colonel Ustra.

\section{Conclusions}

The representation of narratives of violence with the inclusion of all victims, as well as the preservation

53 BRASIL. Tribunal de Justiça De São Paulo. $1^{\text {a }}$ Camara de Direito Privado. Apelaşão Civel 034771808.2009.8.26.0000. Relator: Des. Rui Cascaldi. 14 ago. 2012 of places of violations and resistances, and evidentiary documents are undoubtedly the first steps towards building the rights to truth and memory in the field of transitional justice. The lack of public policies regarding the remembrance of victims or violent acts of repression means the State's failure to its duties of realizing the right to memory. However, if there are public policies in this sense, how can we conclude that they represent human rights violations?

Memorials as a physical expression of a memory-building process are influenced by the political context in which they are involved and by the social actors. In the case of political transitions, the permanence of former influential rulers, the existence of human rights organizations, and the demands of family members influence the process.

In view of the proportions assumed by the violence practiced in Chile and Brazil during the dictatorial periods, as well as the effects of the long duration of military regimes, and in the case of Brazil, given so much time of silence and omission on these facts, it is possible to inquire: at what point will it be possible to consider the right to memory and truth to the point where they reach their goal of non-repetition, even though public policies have been adopted that indicate the fulfilment of their individual and collective dimensions? When you realize that truth and historical memory have reached common subjectivity to the point of producing a culture of human rights that guarantees the non-repetition of violence, as proposed by the Inter-American Court of Human Rights?

If this study does not have the elements to answer these questions, at least it is possible to affirm that, at the moment, these policies need continuity in both countries.

Certainly, it is not up to the law to assess the potential of these policies in relation to the achievement of their purposes. However, it is possible to affirm that if the state has the duty to adopt such policies in order to realize memory and truth in its individual and collective dimensions, with objectives related to reparation of victims and non-repetition, the review of these policies is also included in this duty.

Finally, it must be borne in mind that the objectives of measures of memory and truth lie in the intention of non-repetition of violence. Despite the recognition of the importance of the places of memory existing in 
Chile, the criticisms directed at them in relation to their capacity to contribute to the collective imagination in order to transmit the repudiation of the dictatorship is an opportunity for reflection on the planning of places of memory, so that they better represent the reality of the authoritarian period.

Despite the advances made in terms of memory and truth in Chile, the scope of truth, in its totality, from the individual and collective point of view, has not yet been clarified. This fact is aggravated by the absence of a permanent administrative commission that receives requests from persons who at any moment, for various reasons, were unable or unwilling to present their testimony, and there is therefore no possibility in Chile of those victims being recognized as such by the State, from the individual point of view, except by judicial means.

In the case of Brazil, the completion of the work of the National Truth Commission cannot be considered as an end point. There are still many gaps to be clarified and many measures to be implemented in terms of public memory policies. Issues such as gross violations of human rights against indigenous peoples have been poorly explored, and a specific account of violations of women's rights is lacking in their Report, which in a country with considerable problems of gender inequality and a large number of cases of violence against women, is extremely relevant.

And because of these gaps and the need for permanent remembrance of events for their non-repetition in unstable Brazilian democracy, the work on the realization of the rights to truth and memory needs continuity and deepening.

\section{References}

ABRÃO, Paulo. Justiça de transição no Brasil: o papel da comissão de anistia do Ministério da Justiça. Revista Anistia Política e Justiça de Transição, Brasília, p. 12-22, 2009.

ACUÑA, Carlos H. Transitional justice in Argentina and Chile: a never-ending story? In: ELSTER, Jon (Org.). Retribution and reparation in the transition to democracy. Cambridge: University Press, 2006.

ADORNO, Theodor W. Educación para la emancipación.
Madrid: Morata, 1988.

ARNS, Paulo Evaristo. Brasil: nunca mais. 38. ed. Petrópolis: Vozes, 2009.

BAGGIO, Roberta Camineiro. Justiça de transição como reconhecimento: limites e possibilidades do processo brasileiro. Cadernos IHU Ideias, São Leopoldo, ano 12, v. 12, n. 208, p. 18, 2014.

BAGGIO, Roberta Camineiro. Marcas da memória: a atuação da comissão de anistia no campo das políticas públicas de transição no Brasil. Ciências Sociais da Unisinos, São Leopoldo, v. 48, n. 2, p. 111-118, may/aug. 2012.

BRASIL. Tribunal de Justiça De São Paulo. $1^{\text {a }}$ Camara de Direito Privado. Apelação Civel 034771808.2009.8.26.0000. Relator: Des. Rui Cascaldi. 14 ago. 2012.

COLLINS, Cath. Valech II: ultima instancia de verdad en Chile. Santiago: Universidad Diego Portales, 2012.

COMISIÓN NACIONAL SOBRE PRISIÓN POLÍTICA Y TORTURA. Informe, 2004.

COMISSÃO NACIONAL DA VERDADE. Relatório, ano 3, v. 1, 2014. Available in: <www.cnv.gov.br>. Access: 23 sept. 2015.

CRENZEL, Emilio. Los derechos humanos y las políticas de la memoria: reflexiones a partir de las experiencias de las comisiones de la verdad de Argentina e Chile. In: VINYES, Ricard (Org.). El Estado y la memoria: gobiernos y ciudadanos frente a los traumas de la historia. Buenos Aires: Del Nuevo Extremo, 2009.

FERNÁNDEZ, Karinna Neira. La jurisprudencia de la Corte Suprema Chilena, frente a las graves violaciones contra los derechos humanos cometidos durante la dictadura militar. In: GOMES, Luiz Flávio; MAZZUOLI, Valério de Oliveira (Orgs.). Crimes da ditadura militar. uma análise à luz da jurisprudência atual da Corte Interamericana de Direitos Humanos. São Paulo: Revista dos Tribunais, 2011.

GALINDO, Bruno. Democracia constitucional, justiça transicional e passado autoritário: entre a superação e o "esquecimento". In: MONTEIRO, Roberta Corrêa Araújo; ROSA, André Vicente Pires (Orgs.). Direito constitucional: os desafios contemporâneos (uma homenagem ao Professor Ivo Dantas). Curitiba: Juruá, 2012.

GALINDO, Bruno. Justiça de transição na América do 
Sul: possíveis lições da Argentina e do Chile ao processo constitucional de transição no Brasil. In: FEITOSA, Enoque et al (Orgs.). O judiciário e o discurso dos direitos bumanos. Recife: UFPE, 2012.

GOMES, Luiz Flávio; MAZZUOLI, Valério de Oliveira (Orgs.). Crimes da ditadura militar. uma análise à luz da jurisprudência atual da Corte Interamericana de Direitos Humanos. São Paulo: Revista dos Tribunais, 2011.

HAYNER, Priscilla. Verdades innombrables: el reto de las comisiones de la verdad. México: Fondo de Cultura Económica, 2008.

HITE, Katherine; COLLINS, Cath. Memorial fragments, monumental silences and reawakenings in 21-st century Chile. Millenium: Journal of International Studies, v. 38, n. 2, p. 379-400, 2009.

IACHR. Inter-American Court of Human Rights. Judgment. Case of Barrios Altos v. Peru. San José, 2001.

IACHR. Inter-American Court of Human Rights. Judgment. Case of Castillo-Páez v. Peru. San José, 1997.

IACHR. Inter-American Court of Human Rights. Judgment. Caso Gomes Lund e outros ("guerrilha do Araguaia") vs. Brasil. San José, 2010.

IACHR. Inter-American Court of Human Rights. Judgment. Caso Anzualdo Castro vs. Perú. San José, 2009.

IACHR. Inter-American Court of Human Rights. Judgment. Caso Almonacid Arellano e outros vs. Chile. San José, 2006.

IACHR. Inter-American Court of Human Rights. Judgment. Caso Goiburú e outros vs. Paraguai. San José, 2006.

IACHR. Inter-American Court of Human Rights. Judgment. Caso Tibi vs. Ecuador. San José, 2004.

IACHR. Inter-American Court of Human Rights. Judgment. Caso Myrna Mack Chang vs. Guatemala. San José, 2003.

IACHR. Inter-American Court of Human Rights. Judgment. Caso de los "Niños de la Calle" (Villagrán Morales y otros) vs. Guatemala. San José, 2001.

IACHR. Inter-American Court of Human Rights. Judgment. Caso Bámaca Velásquez. vs. Guatemala. San José, 2000.

IACHR. Inter-American Court of Human Rights. Judgment. Caso Loayza Tamayo vs. Perú. San José, 1998.

IACHR. Inter-American Court of Human Rights. Judg- ment. Caso Benavides Cevallos vs. Ecuador. San José, 1998.

IACHR. Inter-American Court of Human Rights. Judgment. Caso Aloeboetoe y otros vs. Surinam. San José, 1993.

IACHR. Inter-American Court of Human Rights. Judgment. Caso Godínez Cruz vs. Honduras. San José, 1989.

IACHR. Inter-American Court of Human Rights. Judgment. Caso Velásquez Rodríguez vs. Honduras. San José, 1988.

IGREJA Católica do Chile propõe perdoar crimes de militares da ditadura. Euronews. Available in: <http:// pt.euronews.com/2010/07/22/igreja-catolica-do-chile-prope-perdoar-crimes-de-militares-da-ditadura $/>$. Access: 21 sept. 2013.

INSTITUTO DE ESTUDOS DA RELIGIÃO. 4 relatório de monitoramento da comissão nacional da verdade. Rio de Janeiro, 2014. Available in: < http://www.iser.org. $\mathrm{br} /$ website/relatorios-do-monitoramento-dacomissaonacional-da-verdade>. Access: 15 aug. 2013.

INSTITUTO NACIONAL DE DERECHOS HUMANOS. Situación de los derechos humanos en Chile. Informe Anual, Santiago, p. 243-260, 2011. Available in: <http://www.indh.cl/informe2011Inf\%20Anual\%20 INDH12\%20WEB.pdf>. Access: 15 aug. 2013.

INSTITUTO NACIONAL DE DERECHOS HUMANOS. Situación de los derechos humanos en Chile. Informe Anual, Santiago, p. 83-121, 2011. Available in: <http://www.indh.cl/informe2011/Inf\%20Anual\%20 INDH12\%20WEB.pdf>. Access: 15 aug. 2013.

JELIN, Elizabeth: Quiéns? Cuándo? Para qué? actores y escenários de las memorias. In: VINYES, Ricard (Org.). El Estado y la memoria: gobiernos y ciudadanos frente a los traumas de la historia. Buenos Aires: Del Nuevo Extremo: RBA, 2009.

LIRA, Elizabeth. Las resistencias de la memoria: olvidos jurídicos y memorias sociales. In: VINYES, Ricard (Org.). El Estado y la memoria: gobiernos y ciudadanos frente a los traumas de la historia. Buenos Aires: Del Nuevo Extremo: RBA, 2009.

MEMORIALES de derechos humanos en chile: homenaje a las víctimas de violaciones a los derechos humanos entre 1973 y 1990. Santiago: FLACSO, 2007. Available in: <www.issuu.com/flacso.chile/docs/memoriales_doc/4>. Access: 12 aug. 2013.

OBSERVATORIO DE DERECHOS HUMANOS. 
Taller Comisión Valech II. Santiago, 2011.

OLIVEIRA, Roberta Cunha; SILVA FILHO, José Carlos Moreira. Os testemunhos das vítimas e o diálogo transgeracional: o lugar do testemunho na transição pós-ditadura civil-militar brasileira. In: MEYER, Peluso Neder; OLIVEIRA, Marcelo Andrade Cattoni (Orgs.). Justiça de transição nos 25 anos de Constituição. 2. ed. Belo Horizonte: Initia, 2014.

RELATÓRIO da Comissão Nacional da Verdade. Available in: <www.cnv.gov.br>. Access: 23 sept. 2015.

RICHARD, Nelly. Crítica de la memoria. Santiago: Universidad Diego Portales, 2010.

SANTOS, Sheila Cristina. A comissão especial sobre mortos e desaparecidos políticos e a reparação do Estado às vítimas da ditadura militar no Brasil. 2008. Dissertation (Masters) Pontifícia Universidade Católica de São Paulo, São Paulo, 2008.

SECRETARIA ESPECIAL DOS DIREITOS HUMANOS. Direito à verdade e à memória: comissão especial sobre mortos e desaparecidos políticos. Brasília, 2007.

SIERRA, Lucas. Reabrir y cicatrizar: notas sobre el informe Valech y sus reacciones. Anuario de derechos bumanos, Santiago, p. 157-166, 2005. Available in: <http:// www.anuariocdh.uchile.cl/index.php/ADH/article/ viewFile/13350/13624>. Access: 02 jul. 2013.

SIKKINK, Kathryn; WALLING, Carrie Booth. The impact of human rights trials in Latin America. Journal of Peace Research, v. 44, n. 4., p. 427-445, 2007.
STERN, Steve J. Luchando por mentes y corazones: las batallas de la memoria en el Chile de Pinochet. Santiago: Universidad Diego Portales, 2009.

VINYES, Ricard (Org.). El Estado y la memoria: gobiernos y ciudadanos frente a los traumas de la historia. Buenos Aires: Del Nuevo Extremo: RBA, 2009.

WEICH, Marlon Alberto Weichert. A comissão nacional da verdade. In: SILVA FILHO, José Carlos Moreira; TORELLY, Marcelo Dalmás; ABRÃO, Paulo (Orgs.). Justiça de transição nas Américas: olhares interdisciplinares, fundamentos e padrões de efetivação. Belo Horizonte: Fórum, 2013.

ZALAQUETT, José. Derechos humanos e limitaciones políticas en las transiciones democraticas del Cone Sur. Colección Estudios Cieplan, Santiago, n. 33, p. 147-186, 1991.

ZALAQUETT, José. La mesa de diálogo sobre derechos humanos y el proceso de transición política en Chile. Centro de Estudios Públicos, Santiago, n. 79, p. 7-30, 2000. Available in: <http://www.cepchile.cl/1_1124/doc/ la_mesa_de_dialogo_sobre_derechos_humanos_y_el_ proceso_de_transicion_politica>. Access: 04 apr. 2013.

ZALAQUETT, José. La reconstrucción de la unidad nacional y el legado de violaciones de los derechos humanos. Available in: <http://biblioteca.cejamericas.org/bitstream/ handle/2015/609/cl-zalaquettreconstruccion-nacional. pdf? sequence $=1$ \&isAllowed $=y>$. Access: 28 jan. 2017 . 
Para publicar na Revista de Direito Internacional, acesse o endereço eletrônico www.rdi.uniceub.br ou www.brazilianjournal.org.

Observe as normas de publicação, para facilitar e agilizar o trabalho de edição. 